\title{
Geotourism regions - delimitation, classification, basic concepts
}

\author{
Elżbieta GAŁKA
}

\begin{abstract}
The overarching goal of this article is introducing to the literature the term geotourism regions as well as set the basic rules for their delimitation and classification according to strictly established criteria. The term "geotourism region" often occurs in the world literature, but it is usually understood as an area where an evaluation of its geotourism potential is carried out. The lack of a definition results in this term being wrongly interpreted and applied inconsistently. In order to systematize current knowledge on geotourism regions literature review concerning defining and hierarchy of spatially distributed geotourism units was carried out. As a result, for the first time, apart from proposal of the setting basic rules for delimitation and classification of geotourism regions, definitions of geotourism regions, geotourism areas and geotourism destinations were introduced. Introducing the above mentioned concepts could constitute an important starting point of reference for theoretical discussions and practical applications in the fast-growing geotourism industry. Geotourism regions could also constitute a powerful tool in the regional management of geotourism resources. Limitations of studies are very small number of papers devoted to the main topic of the article.
\end{abstract}

Keywords: geotourism regions, geodiversity, geotourism potential, geoheritage

\section{Introduction}

The proposal to introduce the term "geotourism region" to the world literature, as well as basic rules for its delimitation and classification, came into existence as a result of observing constant changes connected with the growing popularity of geotourism. This is also reflected in the number of UNESCO geoparks legislated every year, books and articles devoted to the theoretical and practical aspects of geotourism development, international conferences and workshops (Ólafsdóttir and Tverijonaite 2018).

According to the most commonly used definition "geotourism is a form of natural area tourism that specifically focuses on geology and landscape. It promotes tourism to geosites and the conservation of geodiversity and an understanding of earth sciences through appreciation and learning. This is achieved through independent visits to geological features, use of geo-trails and viewpoints, guided tours, geo-activities and patronage of geosite visitor centres" (Newsome and Dowling 2010).

At present, this discipline has many adherents, not only among professionals, but also amateurs, which translates into growing tourist traffic in areas of great natural interest (Dowling and Newsome 2010). Geoparks, protected areas, health-resorts, post-mining or natural areas within cities are becoming more and more popular. We can describe them by the term "geotourism regions", as distinguished from the definition of tourism region, the prefix "geo" denotes the precisely developed specialization of the area, connected with the development and promotion of Earth sciences. Geotourism regions also play an important role in the economic activation of local communities through implementing sustainable development (Dowling 2013).

DOI: https://doi.org/10.33542/GC2019-2-05 
No definition of geotourism regions has been created in the international literature of the subject so far, with the exception of its first presentation in Żaba and Gaidzik's study (2010), where, according to the authors, geotourism areas and regions are "geotourism areas and regions with special geotourism values, usually protected". The lack of a definition, which would be an important point of reference for theoretical deliberations and practical applications, results in the erroneous interpretation and inconsistent application of this term. There is a clear need to set the basic rules for delimitating geotourism regions and classifying them according to strictly established criteria which refer to aspects such as differentiation of the lithology and the morphology of the terrain, the geotourism potential of the area, the range of influence, and the kind of tourism which could be developed.

The main aim of this article is to systematize current knowledge and introduce into the literature the classification and the basic concepts connected with geotourism regions.

\section{Methods}

In order to systematize current knowledge on geotourism regions narrative, general literature review concerning defining and hierarchy of spatially distributed geotourism units was carried out. This method is traditional literature review comprising a body of text or account that provides a review of the salient and critical aspects of the most current knowledge regarding a topic of interest. The information that drives a general review is typically extracted from the body of extant literature, which includes substantive findings, as well as conceptual, theoretical, and/or methodological contributions to a particular topic (Onwuegbuzie and Frels 2016).

The main goal and the first step of the above mentioned method was evaluation of the present state of knowledge and science investigations on geotourism regions in international magazines and books pertaining to research topic and their practical application and understanding worldwide. In order to do that, after initial analysis of the article's content, classification and selection of the proper source materials were carried out. The main keywords used and searched in ScienceDirect, Elsevier and Google Scholar science web browsers was geotourism region and its derivatives. In the final stage of the first step chronological and thematic approach was used to create tabular listing of the main definetions concerning spatially distributed geotourism units.

The second step was establishment of delimitation rules of geotourism regions and their classification according to differentiated criteria. Final result of verification of the literature content was author's proposal of introducing definitions connected with geotourism regions.

In the field during visiting points of interest such as European geoparks, health resorts, national parks or nature reserves observations of forms and state of tourism development of geological objects were carried out (transport access, development of geoeducational centres, content of geotourism boards, presence of geoproducts, websites and forms of promotion, accommodation and gastronomy base). Additionally the evaluation of the way of knowledge presentation by tourist guides and photographic documentation were carried out. Through illustrations selected types of proposed geotourism regions were presented. In order to do that spatial geological data were taken from Web Map Services (WMS) including Geoportal PGI 2019 as well as Geoportal 2019 websites and elaborated in ArcGis ArcMap 10.4.1 program.

\section{Theory background}

In the world literature we can find different names for a region which has geotourism resources of scientific value and is attractive to tourists. The first basic name of geotourism region applied is geoarea (or geozone), which has the lowest position in the hierarchy of definitions of geotourism region (Tab. 1). Geoareas are usually treated in Asian countries 
as parts of geologically differentiated regions (geo-regions), which together form geoparks (Sewell and Tang 2011, Jing 2016). In China this term refers to areas for protection, recreation, and geotourism activities (Kim et al. 2012).

Tab. 1. Definitions of spatially distributed geotourism units

\begin{tabular}{|c|c|c|}
\hline Term & Definition & Author(s), year \\
\hline geoarea (or geozone) & areas for protection, recreation, and geotourism activities & Kim et al. (2012) \\
\hline georegion & $\begin{array}{l}\text { mappable region in which particular geological, } \\
\text { geomorphic or pedological processes have operated } \\
\text { under particular conditions (or « system controls ») } \\
\text { during a particular period of geological time }\end{array}$ & Sharples (1995) \\
\hline georegion & $\begin{array}{l}\text { regions in which similar system controls (climate, } \\
\text { lithology, geomorphological history, etc.) have produced } \\
\text { similar assemblages of landforms }\end{array}$ & Houshold and Sharples (2008) \\
\hline geo-region & complex geoproduct & Dryglas and Miśkiewicz (2014) \\
\hline georegion & spatial unit of an unspecified taxonomic rank & Zwoliński (2004) \\
\hline georegion (geome) & $\begin{array}{l}\text { higher spatial unit, which is composed of segments } \\
\text { preceding dimensions with heterogeneous structure, but } \\
\text { certain degree of homogeneity which is determined by } \\
\text { the selected common parameters used for the definition }\end{array}$ & Schejbal (2015) \\
\hline geotourism region & $\begin{array}{l}\text { area where an evaluation of geotourism potential is } \\
\text { carried out }\end{array}$ & $\begin{array}{l}\text { Migoń (2005), Krobicki } \\
\text { and Golonka (2008) }\end{array}$ \\
\hline $\begin{array}{l}\text { geotourism areas } \\
\text { and regions }\end{array}$ & $\begin{array}{l}\text { geotourism areas and regions with special geotourism } \\
\text { values, usually protected }\end{array}$ & Żaba and Gaidzik (2010) \\
\hline geopark & $\begin{array}{l}\text { single, unified geographical area where sites and } \\
\text { landscapes of international geological significance are } \\
\text { managed with a holistic concept of protection, education } \\
\text { and sustainable development }\end{array}$ & (UNESCO 2018) \\
\hline
\end{tabular}

The highest rank is given to the term 'georegion'. According to Sharples (1995), a georegion is a "mappable region in which particular geological, geomorphic or pedological processes have operated under particular conditions (or " system controls ») during a particular period of geological time. Each georegion is therefore characterized by particular distinctive types of geological, landform or soil systems". To continue, "georegions as a contextual regions, are defined as a regions in which much the same system controls (climate, lithology, geomorphological history, etc.) have produced similar assemblages of landforms" (Houshold and Sharples 2008). Another definition describes a georegion as a "spatial unit of an unspecified taxonomic rank" (Zwoliński 2004), in which different elements of geodiversity can be classified by at least two important categories: uniqueness and representativeness. In another meaning a georegion (geome) is a "higher spatial unit, which is composed of segments preceding dimensions. It therefore has a heterogeneous structure, but nevertheless has a certain degree of homogeneity which is determined by the selected common parameters used for the definition" (Schejbal 2015).

In the classification of geoproducts, a geotourism region, described as a geo-region, was counted among so-called 'complex geoproducts' (Dryglas and Miśkiewicz 2014). Region presentation as a geoproduct accounts for bigger territorial units and the geodiversity they present (Migon 2012). One such example is the "Land of extinct volcanoes" created in Poland (Pijet-Migon 2016). In this case, a geotourism region could be acknowledged to be a complex geoproduct, because of its possessing natural resources connected with traces of past volcanic activity from different geological periods and tourist infrastructure in the form of the "Trail of extinct volcanoes", a geoeducational centre (Sudecka Zagroda Edukacyjna) 
or educational boards on geotrails. Kaczawa Bloomery or Polish Goldpanning Championships in Złotoryja are included in the geoproduct as geo-events.

Finally, the term "geotourism region" often occurs in the literature, but it is usually understood as an area whose geotourism potential is being evaluated (Migon 2005, Krobicki and Golonka 2008). In the paper "Geotourism - the basic concepts" (Słomka and KicińskaŚwiderska 2004), no definition of geotourism region was introduced. The first short "definition" of geotourism region was proposed by Żaba and Gaidzik (2010), where according to the authors, geotouristic areas and regions are "geotouristic areas and regions with special geotouristic values, usually protected". According to UNESCO, the most important geotourism regions, global geoparks, are "single, unified geographical areas where sites and landscapes of international geological significance are managed with a holistic concept of protection, education and sustainable development" (UNESCO 2018).

The alternative to geotourism regions could be geo-landscapes treated as geomorphologic landscapes (Reynard 2005). According to Necheş and Erdeli (2015), the major components of geolandscapes are geodiversity, biodiversity and cultural values.

In world literature we can also come across the term 'geotourism destinations', but this has also not yet been defined, and usually pertains to geosites and regions with unique geology and geomorphology, which are attractive from the tourism point of view (Newsome, Dowling and Leung 2012, Božic and Tomic 2015, Dowling and Newsome 2017).

In summary, for almost all of the definitions listed in Tab. 1 the common feature is a lack of connections between georesources (geotourism values) and elements typical for all tourism regions, such as (geo)tourist infrastructure development, a transport network and tourist traffic. The main emphasis is placed on the geological aspects of a given region, its protection, forms and processes which are responsible for shaping geological landscapes. This stems from the fact that geotourism constitutes a relatively new field of science, with an extended system of theory connected mainly with the evolution of a definition of geotourism, its connections with geodiversity, geoheritage, geoconservation or geoeducation, but not with the region (area) in which its development takes place (Ólafsdóttir and Tverijonaite 2018).

\section{Basic rules of delimitation of geotourism regions}

In physical-geographical regionalization a leading criterion is geological-geomorphological differentiation (Kondracki 1976), which should also be used when delimiting geotourism regions. The basic rule of the delimitation of a geotourism region is proper delimitation of its borders, which includes an area with internal cohesion and homogeneity, as well as the presence of a feature distinguishing a given area from neighboring terrain (geological background, characteristic relief). All over Poland delimitation of geotourism regions was initiated through the classification of selected geotourism attractions into regional patterns (Migon 2012); evaluation of geotourism potential of loess regions (Solarska et al. 2013) and inventarization of current and potential post-mining regions (Nita and Myga-Piątek 2014).

In the course of delimiting geotourism regions, in order to establish their borders we can examine:

- natural borders in the form of ready, physical-geographical units delimited for particular country or region, which highlight their geodiversity,

- borders of regions, which were determined during regional geodiversity assessment (karst, geothermal, postglacial),

- borders of administrative units (country, city borders),

- ranges of protected areas, including biosphere reserves, national parks or health-resort protection zones. 
The basic criteria for the delimitation of geotourism regions proposed by the author are similar to those applied when establishing geographical and tourism regions, but the focus is on geological aspects:

- areas with outstanding geological and geomorphological value,

- strictly defined borders,

- internal hierarchy,

- internal cohesion, homogeneity and surface continuity,

- development of (geo)tourist facilities,

- transport access,

- tourist traffic (Liszewski 2003, Durydiwka and Kowalczyk 2003).

In the proposed structure of geotourism regions geology is more important for delimitation of georegions than other geographical features because it constitutes the basis for geotourism development (Fig. 1). During the delimitation of geotourism regions the elements of overlapping layers of geological and geographical (physical and socioeconomic) regions should be connected and analyzed.

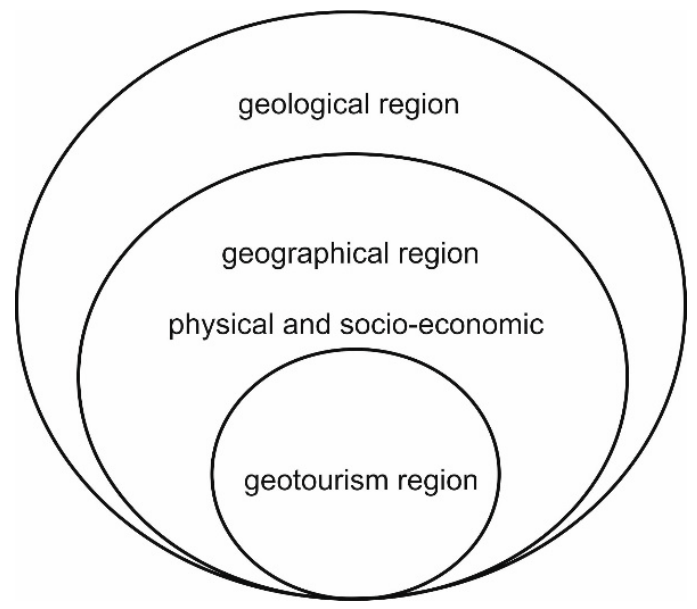

Fig. 1. Structure of geotourism regions; Source: own elaboration

These elements include geological and tectonic settings, geomorphology, forms of landscapes, biodiversity, material and non-material heritage, infrastructure or level of the economic development of the area. Geotourism regions connect the natural and socio-economic features of a given region, for example, through the establishment of geoparks, where environmental conditions are examined taking socio-economic aspects into consideration. This approach is in contrast to the current trend in tourism, where tourism regions are only examined from the socio-economic point of view (Kozak 2009), or are regarded as a disaggregation of physical and socio-economic regions (Knox 1998, Brzezińska-Wójcik and Świeca 2016).

\section{Classification of geotourism regions}

A first essential criterion for delimiting geotourism regions is the occurrence of areas with unique geological values, where geotourism is developing and generating tourist traffic. Without doubt we can count to among geoparks - specialized geotourism regions open to the public that cultivate holistic, sustainable development, and whose main task is to popularize and broaden tourists' knowledge about heritage through visiting points of interest and participating in geo-activities (Fig. 2). Such regions are ranked highest in the hierarchy of geotourism regions proposed by the author of this article. 

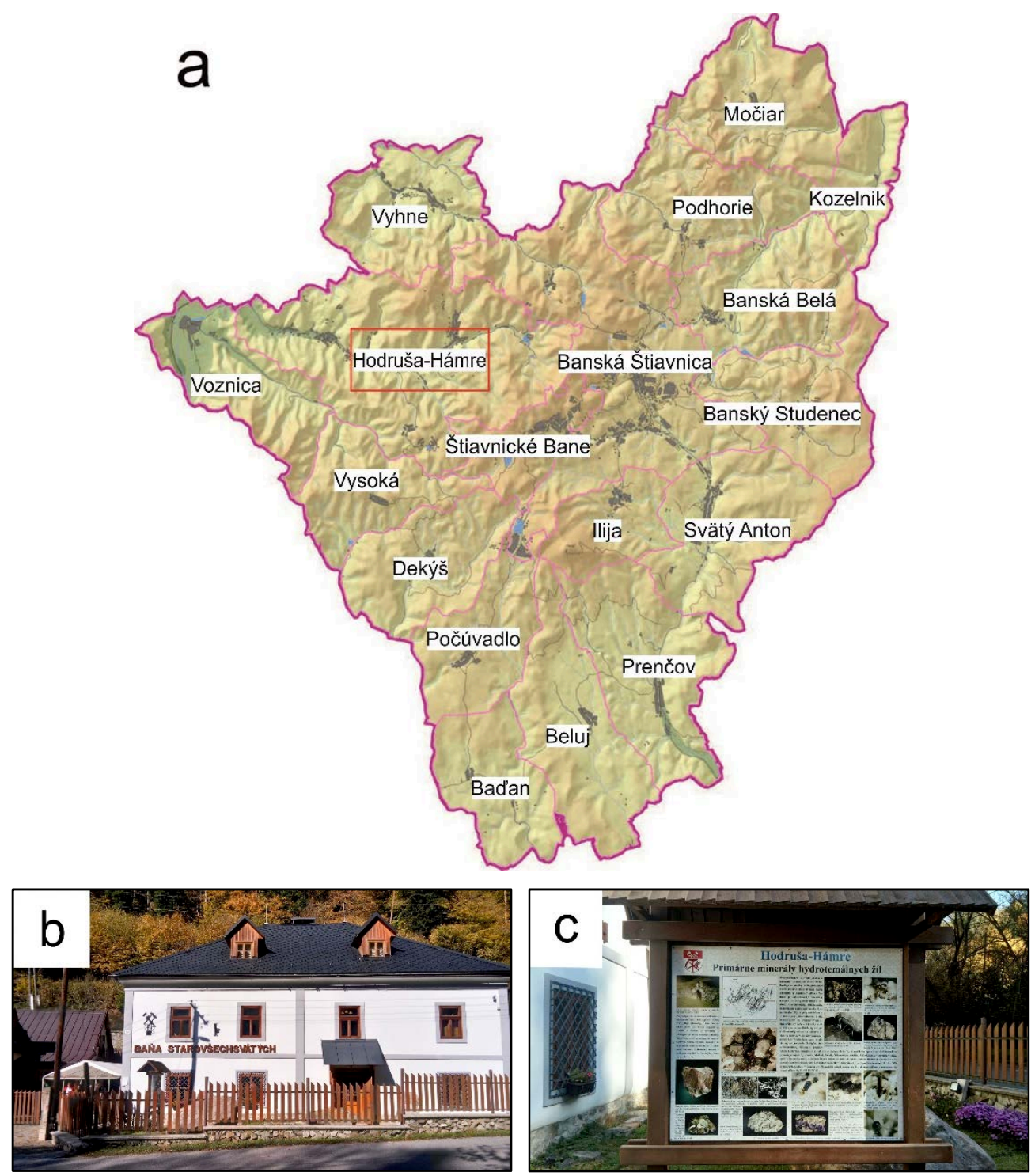

Fig. 2. Banská Štiavnica UNESCO Global Geopark, Slovakia; a) Map of the geopark with the localization of Hodruša-Hámre mining center; Source: Geoparks in Slovakia 2019; b) All Saints Mine exhibition house in Hodruša-Hámre; c) Geotouristic board describing minerals of hydrothermal veins situated next to exhibition house; Source: E. Gatka

The next group of geotourism regions are protected areas, such as biosphere reserves, national parks (Fig. 3), protected landscapes, landscape parks or nature reserves. The most valuable geological areas are promoted in the form of geoparks, geological parks or geotourist routes. Within protected areas, geotourism combines with other kinds of outdoor activities, such as ecotourism, qualified and cultural tourism or sightseeing. The range of the geoparks could overlap completely with the range of protected areas, as is usually the case with biosphere reserves (Jeju Island Unesco Global Geopark) or national parks. Geoparks' borders could also overlap with the most valuable parts of a protected area (Lanzarote and Chinijo Islands Geopark). 

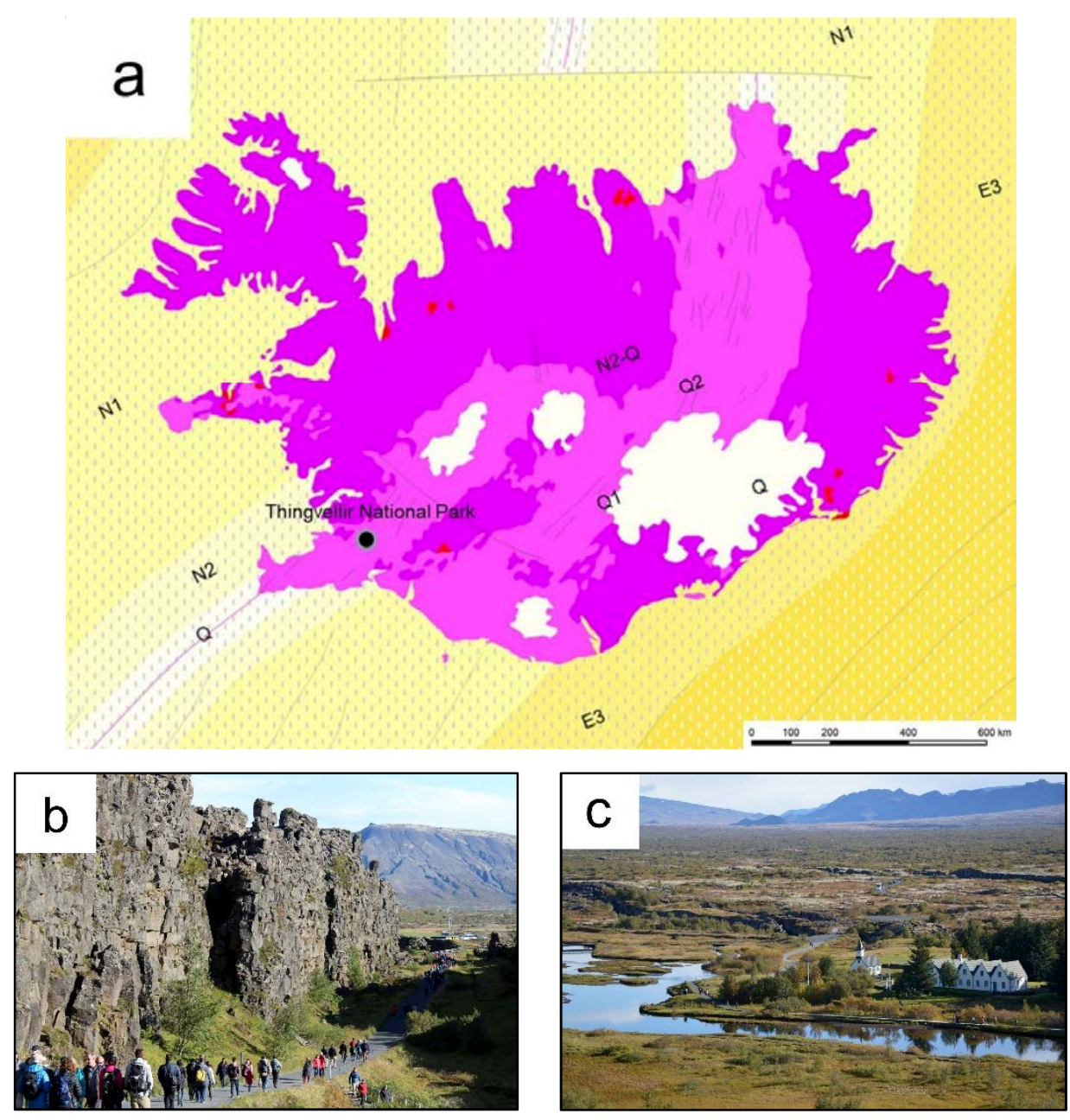

Fig. 3. Thingvellir National Park, Iceland: a) Localization of park on the background of geological map of the Iceland. Mainland: $Q$ - volcanite Quaternary, basalt group, $Q 1$ - volcanite Quaternary, basalt group, Pleistocene; Q2 - volcanite Quaternary, basalt group, Holocene, N2-Q - volcanite Cenozoic basalt group, Pliocene-Quaternary. Oceanic crust: $Q$ - younger, tholeiitic basalt; N2 - younger, tholeiitic basalt, Pliocene; N1 - younger, tholeiitic basalt, Miocene; E3 - younger, tholeiitic basalt, Oligocene; E2 - older, tholeiitic basalt, Eocene; Source: Geoviewer BGR 2019, changed; b) Tourist admiring numerous lava lobes in Almannagjá; Source: A. Wojtyna; c) Landscape of the Pingvellir rift valley; Source: K. Kacprzak

Different specificity can be ascribed to functional health resort geotourism regions with outstanding bioclimatic and therapeutic merit, as well as natural geological resources which constitute the basis for health resort medical services, as well as creating geoparks (Miśkiewicz et al. 2011). Observations of spouting geysers (Iceland, Rotorua region), balneotherapy in geothermal lakes or pools (Heviz, Blue Lagoon, Bad Blumau) (Fig. 4), and underground salt mines (Turda, Bochnia, Wieliczka) make such places attractive to clients and tourists. These areas are well developed for tourism and their range is limited by zones of health resort protection (Fig. 5). 

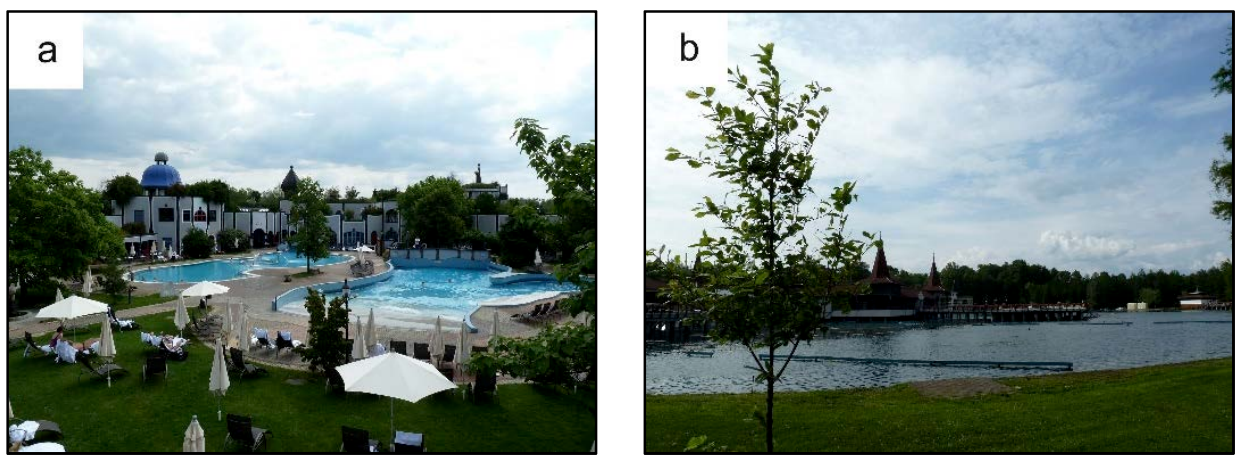

Fig. 4. European geothermal health resorts: a) Balneotherapy pool in Bad BlumauHundertwassser's architectural project, Austria; b) Geothermal lake in Heviz, Hungary; Source: E. Gatka

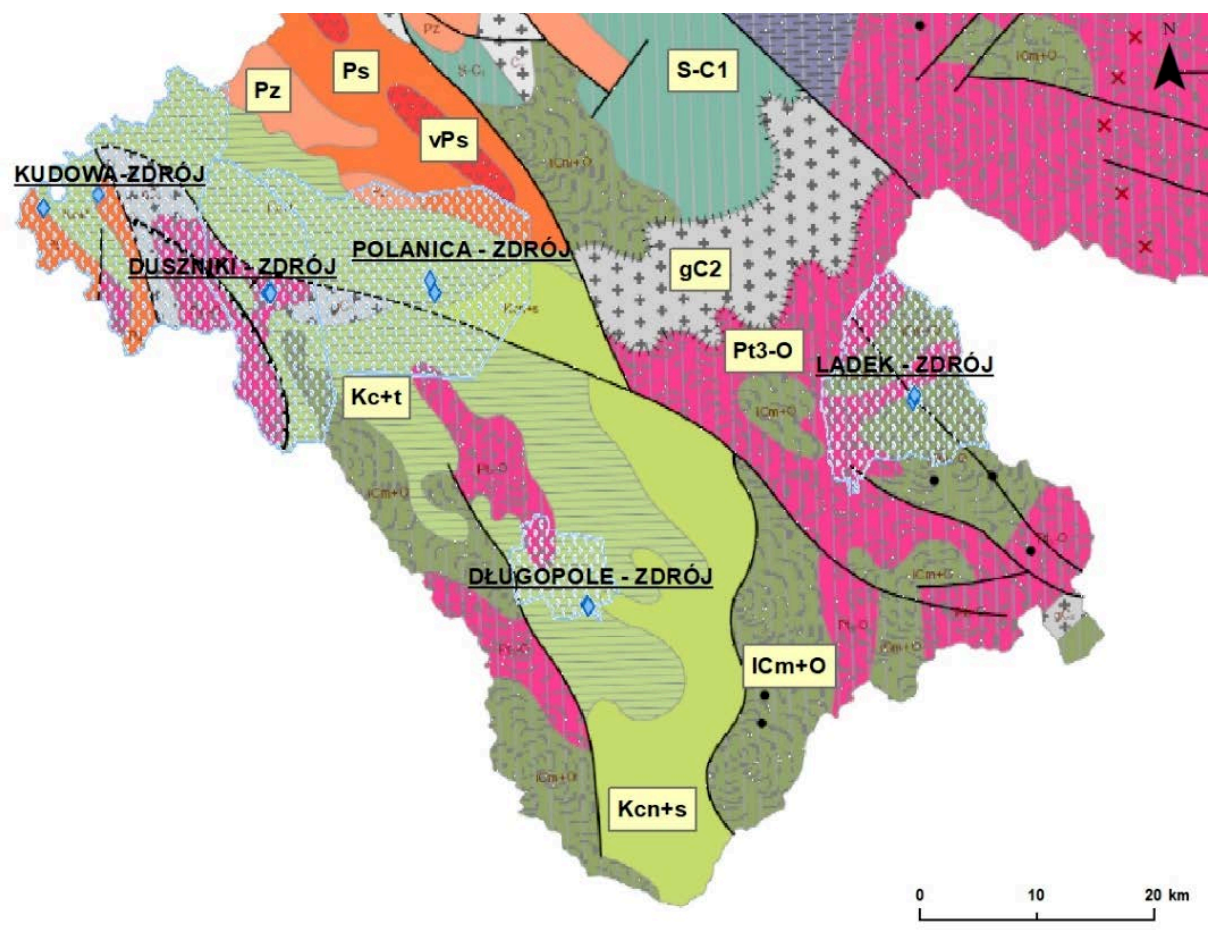

Fig. 5. Health resorts and their protection zones on the background of the geology of the Kłodzko Basin, Poland; Pt3-O - Upper Proterozoic-Ordovician; ICm+O - Cambrian and Ordovician - igneous rocks; S-C1 - Silurian-Lower Carboniferous; gC2 - Upper Carboniferous - granitoids; Ps - Rotliegend; vPs - Rotliegend-volcanic rocks; Pz Zechstein; $\mathrm{Kc}+t-$ Cenomanian and Turonian; $\mathrm{Kcn}+s-$ Coniacian and Santonian; Source: Geoportal PGI 2019, changed

Adapted and non-adapted post-mining areas constitute real and potential geotourism regions, respectively. Geoparks, geological parks, geoeducational centres, geological didactic trails or viewpoints are created within such areas (Nita and Myga-Piątek 2014, Perelló et al. 2017) (Fig. 2). On account of their unique character, they are often used for cultural purposes. 
The next geotourism regions to be presented are urban areas, within which city geotourism is developing (Ng, Fung and Newsome 2010, Chylińska and Kołodziejczyk 2018). These regions possess natural and anthropogenic geotourism resources and a suitable infrastructural base. The origin of post-exploitation forms protected in the form of geopark or nature reserves is connected mainly with local building and industry demands (Fig. 6). Geological museums, geoeducational centers, geotouristic routes, underground tourism routes or open-air exhibitions all have an educational function.

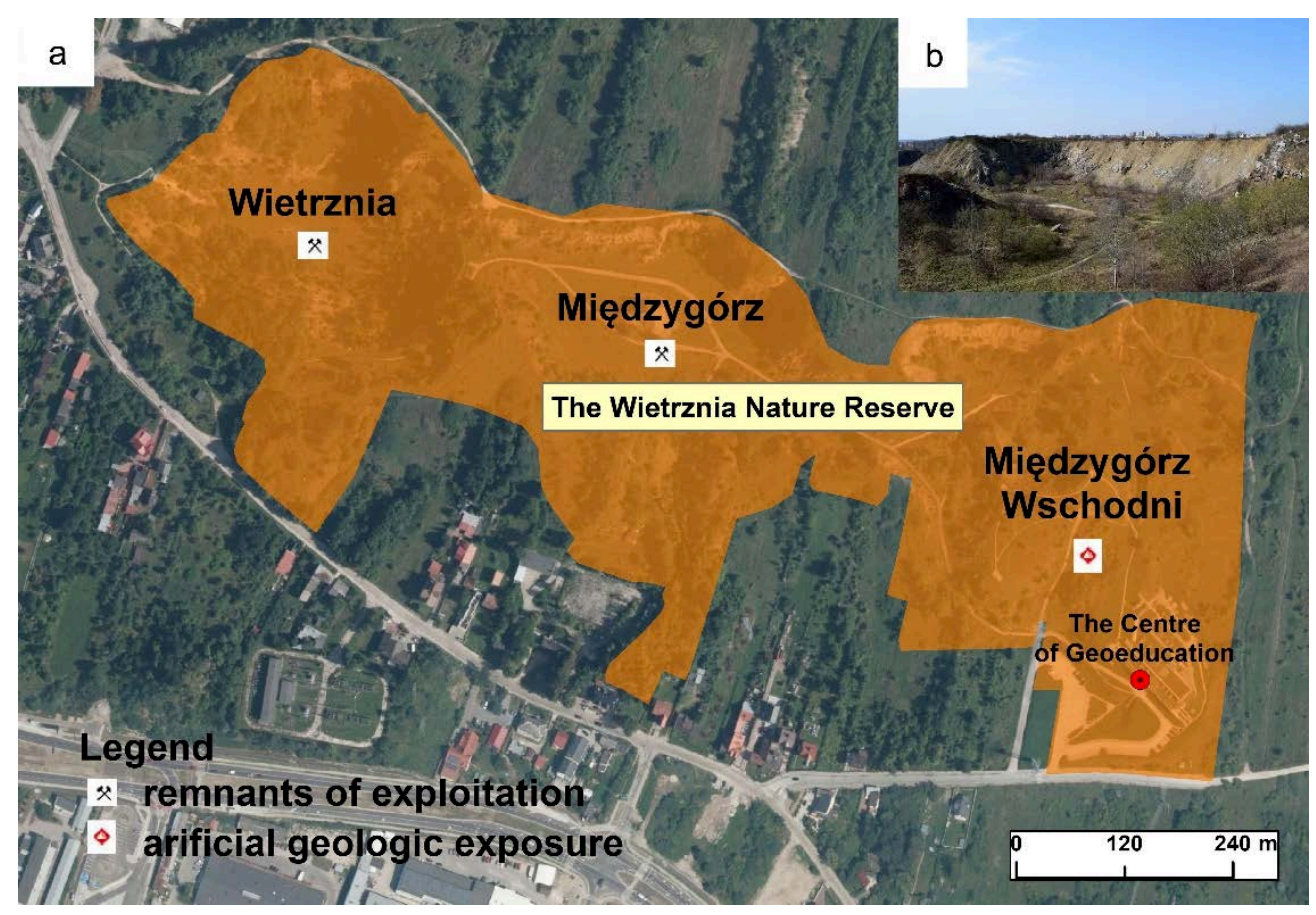

Fig. 6. Geoland of the Holy Cross Mts Geopark - The Wietrznia Nature Reserve, Kielce, Poland; a) Localization and extent of the Wietrznia Nature Reserve on the background of the ortofotomap; Source: Geoportal 2019, Geoportal PGI 2019, changed. b) Międzygórz Wschodni devonian limestones and dolomites quarry; Source: E. Gatka

The final type of geotourism region proposed here, in which geotourism is developing, are transboundary regions (Fig. 7). The main goal of international cooperation entered into in order to open to the public, development and promotion of geological objects is the economic activation of peripheral regions and geoinfrastructure implementation (Koźma and Kupetz 2008, Horváth and Csüllög 2013).

During the delimitation and classification of remaining geotourism regions the following criteria were considered: the degree of differentiation of geology and geomorphology, the region's potential, the range of influence and kind of tourism connected with geology, and the relief of the terrain. A basic, simple classification according to the morphology of the terrain is the classification of geotourist macroregions: coastal, lake district, lowland, upland and mountain. Within these regions we can distinguish mesoregions, for instance, limestone upland karst areas, postglacial high-mountains or coastal dune areas. Within mesoregions microregions could be selected and limited to river catchments or mountains as a part of geomorphological landcapes (Reynard 2005). 

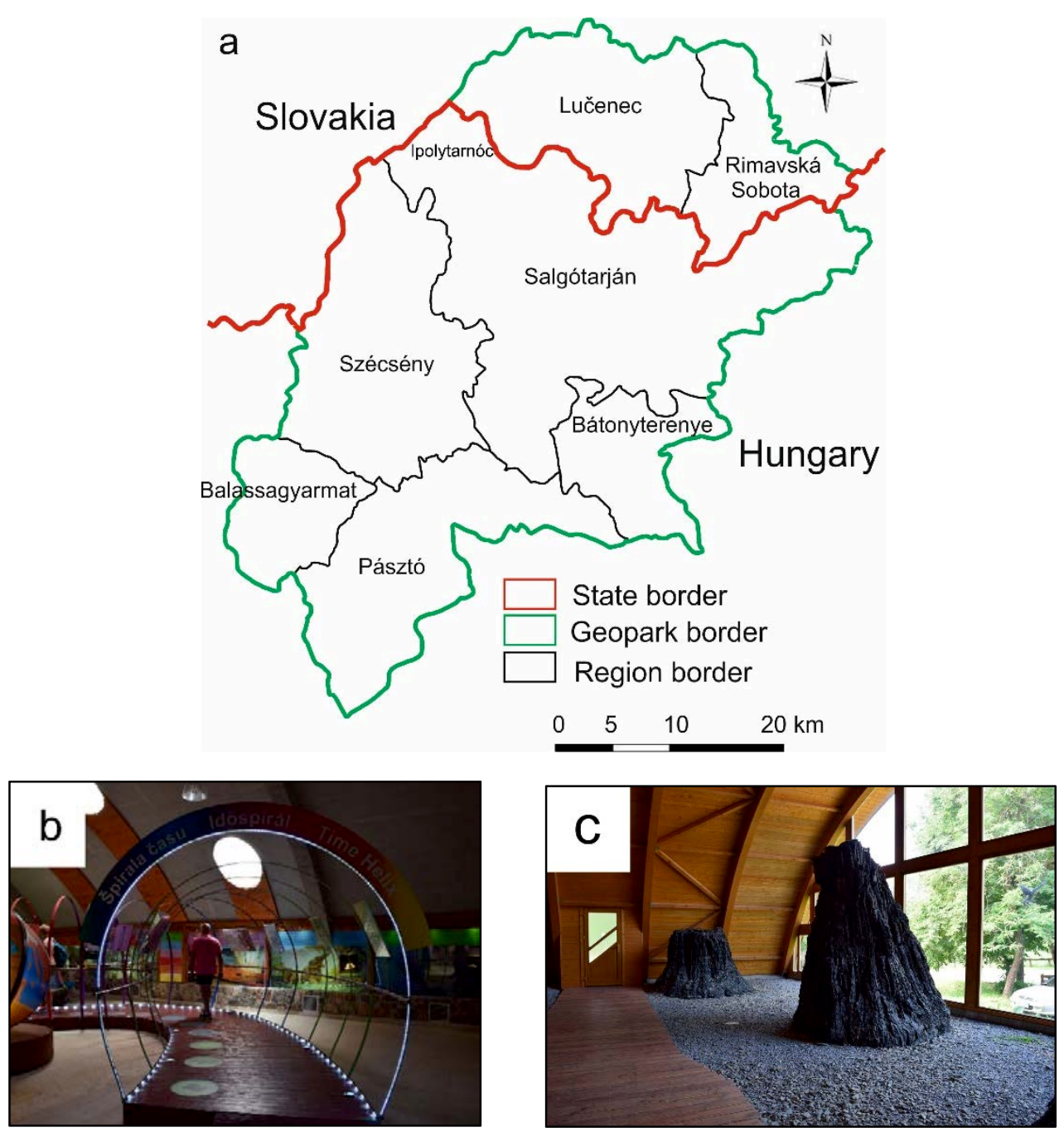

Fig. 7. Transnational Novohrad-Nógrád UNESCO Global Geopark, Hungary;

a) Localization of Ipolytarnóc educational centre on the map of geopark; Source: Szarvas 2019, changed; b) Time Helix in the Ipolytarnóc in situ interpretative centre; c) Swamp cypresses in the Fossil Remains Park of Ipolytarnóc; Source: E. Gatka

The proposed classification of geotouristic regions according to the geodiversity of the terrain includes homogeneous geotourism regions with one dominant geological background (for instance, karst, volcanic, loess, gypsum, geothermal) (Fig. 3) and heterogeneous geotourism regions, which include a diversified geological area (Fig. 5). In the case of homogeneous geotourism regions, we must quote Schejbal's (2015) definition and note the "heterogeneous structure, but certain degree of homogeneity which is determined by the selected common parameters".

Going further in our analysis, we can distinguish real and potential geotourism regions: real geotourism regions with geotourism value and a suitable tourism infrastructure, where tourist traffic is concentrated (geoparks, national parks) (Fig. 2, 3), and potential areas, for example the Bieszczady Mts, Poland, which are of merit in terms of geotourism, but without a geotourism infrastructure or at the initial stage of developing one. 
The classification of geotourism regions according to the range of influence comprises international, national, regional and local regions. International geotourism regions are internationally known and recognized, the most spectacular attracting the attention of international tourists, whose numbers often reach several million visitors per year (The Grand Canyon, Yellowstone National Park, Cappadocia, Norway's fiords). These regions also play an important role in explaining the Earth's evolution and constant changes connected with the exogenic and endogenic processes shaping our planet (Thingvellir National Park, Grand Canyon) (Fig. 3). National geotourism regions are often the flagship areas of a given country, and are visited by an international tourists thanks to their outstanding geological and geomorphological value (Fig. 2). Regional geotourism is limited to selected areas of a country, where favorable natural conditions exist for geotourism to develop (national geoparks, national parks or postmining areas) (Fig. 6). Local geotourism regions play a crucial role in field investigations, geoeducation and geoconservation management.

The last classification proposed here is a classification of geotourism regions according to the kind of tourism connected with the geology and geomorphology of the terrain. We can distinguish regions with qualified tourism, city geotourism, health tourism and cognitive tourism, which include such forms of tourism as cultural, culinary tourism, enotourism, ecotourism or sightseeing. Qualified tourism represents such forms of tourism as ice trekking (Jostedalsbreen Glacier), diving (Blue Hole, Bahamas), speleology (Moravian Karst), highaltitude trekking (Himalayas) or canoeing (Grand Canyon). Enotourism and culinary tourism also show close relationships with geotourism by investigating the main geodiveristy elements such as geology, geomorphology and soil quality (Fig. 8).
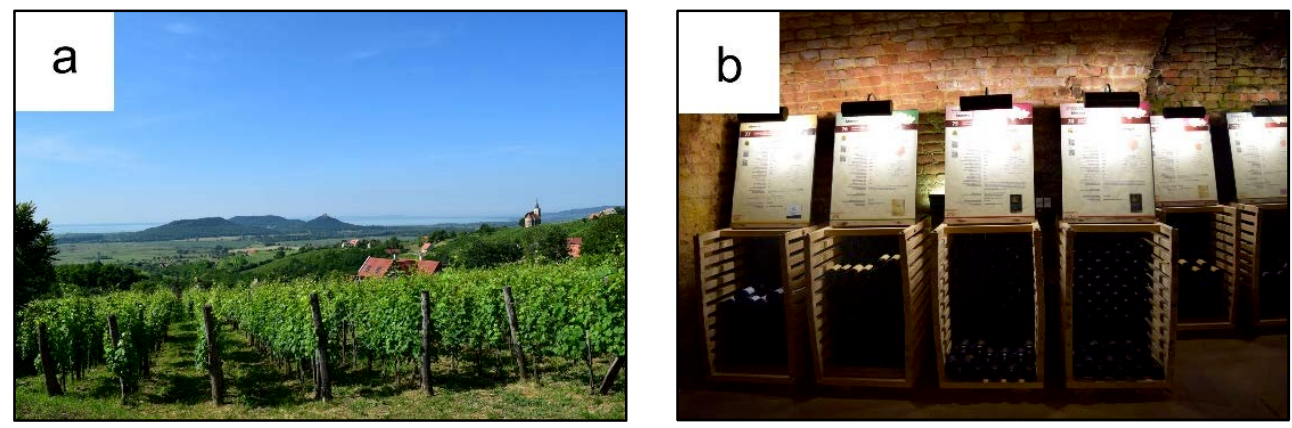

Fig. 8. European wine regions: a) Vineyards at the foot of Saint George's basalt hill in the Bakony - Balaton Global Geopark, Hungary; b) Exhibition devoted to Moravian wine types prepared for the purpose of tasting in the undergrounds of Valtice castle, Czech Republic; Source: E. Gatka

Finally, on the basis of a literature review, the following definitions of basic concepts connected with geotourism regions were created:

Geotourism destination - place or region which constitutes the main goal for travel and stays for admirers of nature (professionals and non-professionals)

Geotourism areas (geo-areas) - a fragment of a geotourism region where the geotourism potential is used for field investigations, geoeducation, outdoor geoactivities, recreation and geoconservation managment

Geotourism regions - regions which perform science, educational and promotional functions due to the geological and geomorphological values of a given area, possess convenient transport links and a geotourism infrastructure, stimulate economic growth, integrate the local community and sustain its tradition and culture through sustainable development 


\section{Discussion}

Presented definitions in table 1 express spatially distributed geotourism units from small scale areas (geoareas, geotourism destinations) to large scale regions (georegions, geoparks). The term geoarea very seldom occurs in the literature concerning geotourism regions and has the lowest meaning. We can treat such areas as a main component parts of gelogical attractive regions, where geotourism potential is evaluated paying special attention to science, educational and recreational needs.

Definition of georegion was introduced much earlier than geoarea as a basic spatial unit used to science investigations. The first presentation of definition of georegion focused on natural factors responsible for shaping relief of the terrain and reveals close relationships with the Earth sciences including physical-geographical characteristsic of given region (Sharples 1995; Houshold and Sharples 2008). Its rank was increased by Schejbal (2015) to „highest spatial unit“.

Along with geotourism development equally important as a geological settings of the region became its geotourism value and its protection. Such regions are contemporary "anew" discovered for tourists, investigated and evaluated paying special attention to geotourism potential (Migoń 2005, Krobicki and Golonka 2008, Żaba and Gaidzik 2010). Nowadays popularization of this relatively new field of science has a great influence on emerging geotourism oriented specialized areas, which comprise regions with outstanding geotourism value and infrastructure such as geoeducational centers, trails and informative panels. Such regions were described by Dryglas and Miśkiewicz (2014) as a georegions - complex geoproducts. Rogowski (2016) on the basis of above mentioned work evaluated potential of the Sudetes Mountains (Poland) for the development of geotourism product and for the first time in the literature distinguished the „first rate" and the „second rate" geotourism regions.

Definition of geoparks is the closest to proposed by the author definition of geotourism regions, it explains the essence of the idea of geotourism regions more fully, in holistic way. It conveys geopark concept promoting areas with international geological meaning in which the main attention is put on the sustainable development. Definition of geo-landscapes next to the geodiversity put pressure on biodiversity and cultural values, but it is also essential from geomorphological point of view. Definition of geotourism destinations wasn't created like so far and pertains to objects or regions with high geological value, spectacular, attracting the highest number of tourists.

To sum up, common feature of almost all of the definitions concerning spatially distributed units is a lack of connections between georesources (geotourism values) and elements typical for all tourism regions, such as (geo)tourist infrastructure development, a transport network and tourist traffic. In the science research concerning geotourism the main emphasis is placed on the evolution of a definition of geotourism, its connections with geodiversity, geoheritage, geoconservation or geoeducation, but not on the region (area) in which its development takes place.

After literature review concerning defining and hierarchy of spatially distributed geotourism units we can notice that there is a lack of common, one homogeneous definition of geotourism region. On the other hand we can distinguish and connect these elements of above mentioned definitions, which fulfill requirements and could be used to create such term.

Proposed by the author of this article classification and basic concepts are the first trial to systematize knowledge concerning geotourism regions. For the first time short definition of geotourism destination was created and pertains to place or region as the main goal for travel and stays for admirers of nature (professionals and non-professionals). Position of geotourism destination definition is the lowest in the hierarchy, but from the tourist point of view geotourism destinations next to the geoparks are the most valuable and spectatcular regions attracting every year international visitors. Definition of geoturism areas increased the rank of such areas from playing typical, recreational functions (Kim et al. 2012) 
to component part of geotourism regions - areas possesing primarily geotourism potential used to science investigations, geoeducation and protection of objects of inanimate nature.

In proposed by the author presentation definition of geotourism regions consist not only of geological values, but also added value such as geoinfrastructure or communication network. They play science, educational, economic and promotional functions with respectting sustainable development rules. Such proposed presentation of the geotourism region is holistic and helpful in investigating comprehensive of regional aspects of geotourism development. According to the author of this article geotourism regions connect the natural and socio-economic features of a given region, for example, through the establishment of geoparks, where environmental conditions are examined taking socio-economic aspects into consideration. This approach is in contrast to the current trend in tourism, where tourism regions are only examined from the socio-economic point of view (Kozak 2009), or are regarded as a disaggregation of physical and socio-economic regions (Knox 1998, Brzezińska-Wójcik and Świeca 2016).

\section{Conclusions}

Constant changes connected with the growing popularity of geotourism in areas of great natural interest such as geoparks, protected areas, health-resorts, post-mining or natural areas within cities, induced author of this article to focus attention on regional aspects of geotourism development. As a result, on the basis of literature review, for the first time definitions of geotourism regions, geotourism areas and geotourism destinations were created as well as basic rules of delimitation and classification of geotourism regions according to strictly established criteria were described.

Although growing popularity of geotourism, knowledge concerning geotourism regions is still in the initial stage of development. There are only few papers devoted to defining and delimitation of geotourism regions, the remaining vast majority concern geotourism potential assessment. Moreover, it was stated, that common feature of almost all of the definitions concerning spatially distributed units is a lack of connections between georesources (geotourism values) and elements typical for all tourism regions, such as (geo)tourist infrastructure development, a transport network and tourist traffic. The main emphasis is placed on the evolution of a definition of geotourism, its connections with geodiversity, geoheritage, geoconservation or geoeducation, but not with the region (area) in which its development takes place. Also all the terms related to spatially distributed geotourism units mentioned and described in this article occur in the world literature, but despite their common application, some have not yet been defined or are applied incorrectly, (for instance, the term "geoarea" or "geotourism destinations"). Furthermore, their geographical distribution is uneven. Through introducing to the world literature definitions of geotourism regions and the basic rules of their delimitation and classification there is a chance to fill this gap of knowledge. The article also represents a valuable contribution to the future potential discussions on geotourism regions.

Further research should be focused on issues concerning regional geotourism development, such as: delimitation of areas with significant geotourism potential, hierarchy of geotourism regions, statistical analysis and studies on the state of the geotourism infrastructure and tourist traffic in the region.

Moreover, establishment of geotourism regions will help to carry out investigations on the tourism capacity and absorption in the region, implementation of an idea of sustainable development, improvement the geotourist infrastructure and economic activation of peripheral regions, building an integrated geoproduct as well as a brand which distinguishes a region. Additional practical applications of science investigations are integrated activities in order to protect nature, possibility to apply for subsidies for the development and promotion of the region, and finally, engagement in the large-scale promotion of regions within and outside of the country. 


\section{References}

BOŽIC, S., TOMIC, N. 2015: Canyons and gorges as potential geotourism destinations in Serbia: comparative analysis from two perspectives - general geotourists and pure geotourists. Open Geosciences, 7(1), 531-546. DOI: https://doi.org/10.1515/geo-2015-0040.

BRZEZIŃSKA-WÓJCIK, T., ŚWIECA, A. 2016: Region - aspekty teoretyczne i wymiar praktyczny. In Brzezińska-Wójcik, T., Skowronek, E., Świeca, A. eds. Od regionu geograficznego do regionu turystycznego. Lubelszczyzna - implikacje historyczne, teoretyczne, naukowo-badawcze, edukacyjne. Lublin (Wydawnictwo UMCS), pp. 1-195.

CHYLIŃSKA, D., KOLODZIEJCZYK, K. 2018: Geotourism in an urban space? Open Geosciences, 10(1), 297-310. DOI: https://doi.org/10.1515/geo-2018-0023.

DOWLING, R. K. 2013: Global Geotourism - An Emerging Form of Sustainable Tourism. Czech Journal of Tourism, 2(2), 59-79. DOI: https://doi.org/10.2478/cjot-2013-0004.

DOWLING, R. K., NEWSOME D. 2010: Global Geotourism Perspectives. Oxford (Goodfellow Publishers).

DOWLING, R. K., NEWSOME, D. 2017: Geotourism Destinations - Visitor Impacts and Site Management Considerations. Czech Journal of Tourism, 6(2), 111-129. DOI: https://doi.org/10.1515/cjot-2017-0006.

DRYGLAS, D., MIŚKIEWICZ, K. 2014: Construction of the geotourism product structure on the example of Poland. In 14th GeoConference on Ecology, Economics, Education and Legislation conference proceedings, Vol. 3. International Multidisciplinary Scientific Geoconferences 17-26 June 2014, Albena, Bulgaria, Ecology and environmental protection. Sofia (STEF92 Technology Ltd), pp. 155-162. DOI: https://doi.org/10.5593/ SGEM2014/B52/S20.021.

DURYDIWKA, M., KOWALCZYK, A. 2003: Region turystyczny a procesy globalizacji. Turyzm, 13(1), 21-42.

GEOPARKS IN SLOVAKIA 2019: Banská Štiavnica Geopark. Official Geoparks in Slovakia Website [cit. 2019-08-12]. Retrieved from: http://www.geopark.sk/en/ banskostiavnicky_geopark-en/c.

GEOPORTAL 2019: View Service (WMS). Official Geoportal of National Spatial Data Infrastructure Website [cit. 2019-08-11]. Retrieved from: https://www.geoportal.gov.pl/ uslugi/usluga-przegladania-wms\#.

GEOPORTAL PGI 2019: Services WMS \& WFS. Official Polish Geological Institute National Research Institute Website [cit. 2019-08-10]. Retrieved from: http://geoportal.pgi.gov.pl/uslugi_gis.

GEOVIEWER BGR 2019: Geoviewer of Federal Institute for Geosciences and Natural Resources (GDI-BGR) in Hannover. Retrieved from: https:/geoviewer.bgr.de/mapapps4/ resources/apps/geoviewer/index.html?lang=en.

HORVÁTH, G., CSÜLLÖG, G. 2013: A new Slovakian - Hungarian cross-border geopark in central Europe - possibility for promoting better connections between the two countries. European Countryside, 5(2), 146-162. DOI: https://doi.org/10.2478/euco-2013-0010.

HOUSHOLD, I., SHARPLES, C. 2008: Geodiversity in the wilderness: a brief history of geoconservation in Tasmania. In Burek, C. V., Prosser C. D. eds. The history of geoconservation. London (The Geological Society), pp. 257-272. DOI: https://doi.org/ 10.1144/SP300.20.

JING, Z. 2016: Popularization program of China Fangshan Global Geopark. In 7th International Conference on UNESCO Global Geoparks, 27th-30th September 2016 Book of abstracts. English Riviera Unesco Global Geopark (UNESCO), p. 145.

KIM, H. H., KOMOO, I., LEE, Y. I., MARTINI, G. 2012: World Natural Heritage and Environmental Conservation. New Asia for Peace and Prosperity. The 6th Jeju Forum for Peace and Prosperity. Jeju (Jeju Peace Institute), pp. 183-187. 
KNOX, P. L. 1998: Places and Regions in Global Context. Upper Saddle River (Prentice - Hall). KONDRACKI, J. 1976: Podstawy regionalizacji fizycznogeograficznej. Warszawa (PWN).

KOZAK, M. W. 2009: Regiony turystyczne: aspekty użyteczności pojęcia. Folia Turistica, $21,185-203$.

KOŹMA, J., KUPETZ, M. 2008: The transboundary Geopark Muskau Arch (Geopark Łuk Mużakowa, Geopark Muskauer Faltenbogen). Przeglad Geologiczny, 56, 8(1), 692-698.

KROBICKI, M., GOLONKA, J. 2008: Podhale Palaeogene Flysch as geotouristic region first look to its unique geological values. Geoturystyka, 2(13), 27-46. DOI: https://doi.org /10.7494/geotour.2008.13.25.

LISZEWSKI, S. 2003: Region turystyczny. Turyzm, 13(1), 43-54.

MIGON, P. 2005: Górne Łużyce jako region geoturystyczny. Geoturystyka, 2(2), 23-32.

MIGOŃ, P. 2012: Geoturystyka. Warszawa (PWN).

MIŚKIEWICZ, K., GOLONKA, J., WAŚKOWSKA, A., DOKTOR, M., SŁOMKA, T. 2011: Transgraniczny geopark Karpaty fliszowe i ich wody mineralne. Przeglad Geologiczny, 59(9), 611-621.

NECHEŞ, I. M., ERDELI, G. 2015: Geolandscapes and Geotourism: Integrating Nature and Culture in the Bucegi Mountains of Romania. Landscape Research, 40(4), 486-509. DOI: https://doi.org/10.1080/01426397.2014.939616.

NEWSOME, D., DOWLING, R. K. 2010: Setting an agenda for geotourism. In Newsome, D., Dowling, R. eds. Geotourism: The Tourism of Geology and Landscape. Oxford (Goodfellow Publishers), pp. 1-12.

NEWSOME, D., DOWLING, R., FAI LEUNG,Y. F. 2012: The nature and management of geotourism: A case study of two established iconic geotourism destinations. Tourism Management Perspectives, 2(3), 19-27. DOI: https://doi.org/10.1016/j.tmp.2011.12.009.

NG, Y. C. Y., FUNG, L. W., NEWSOME, D. 2010: Hong Kong Geopark: uncovering the geology of a metropolis. In Dowling, R. K., Newsome, D. eds. Global Geotourism Perspectives. Oxford (Goodfellow Publishers), pp. 179-191.

NITA, J., MYGA-PIĄTEK, U. 2014: Geotourist potential of post-mining regions in Poland. Bulletin of Geography - Physical Geography Series, 7, 139-156. DOI: https://doi.org/10.2478/bgeo-2014-0007.

ONWUEGBUZIE, A. J., R FRELS, R. 2016: Seven steps to a comprehensive literature review: A multimodal and cultural approach. SAGE Publications Ltd.

ỎLAFSDỎTTIR, R., TVERIJONAITE, E. 2018: Geotourism: a systematic literature review. Geosciences, 8(234), 1-16. DOI: https://doi.org/10.3390/geosciences8070234.

PERElló, J. M., CARRIÓN, P., MOLINA, J., VILLAS-BOAS, R. 2017: Geomining Heritage as a Tool to Promote the Social Development of Rural Communities. In Reynard, E., Brilha, J. eds. Geoheritage. Assessment, Protection, and Management. Elsevier (Amsterdam, Oxford, Cambridge), pp. 167-177. DOI: https://doi.org/10.1016/ B978-0-12-809531-7.00009-5.

PIJET-MIGOŃ, E. 2016: Geoturystyka - nowe możliwości wykorzystania dziedzictwa Ziemi w turystyce. Studium przypadku Krainy Wygasłych Wulkanów w Sudetach Zachodnich. Ekonomiczne Problemy Turystyki, 1(33), 301-312. DOI: https://doi.org/ 10.18276/ept.2016.1.33-24.

REYNARD, E. 2005 : Géomorphosites et paysages. Géomorphologie, 11(3), 181-188. DOI: https://doi.org/10.4000/geomorphologie.338.

ROGOWSKI, M., 2016: The potential of the Sudetes Mountains for the development of geotouristic products. Geotourism, 3-4 (46-47): 59-80. DOI: http://dx.doi.org/10.7494/ geotour.2016.46-47.59. 
SEWELL, R. J., TANG, D. L. K. 2011: Geology of the Hong Kong National Geopark. Proceedings of the Seminar on Geopark, Conservation and Sustainable Development 24 June 2011, pp.1-17.

SHARPLES, C. 1995: Geoconservation in forest management - principles and procedures. Tasforests, 7, 37-50.

SCHEJBAL, C. 2015: Proposal for classification of diversity structure in geoscience and montanistic tourism. Procedia Earth and Planetary Science, 15, 649-655. DOI: https://doi.org/10.1016/j.proeps.2015.08.074.

SŁOMKA,T., KICIŃSKA-ŚWIDERSKA, A. 2004: Geoturystyka - podstawowe pojęcia. Geoturystyka, 1, 5-7.

SOLARSKA, A., HOSE, T. A., VASILJEVIĆ, D. A., MROCZEK, P., JARY, Z., MARKOVIĆ, S. B., WIDAWSKI, K. 2013: Geodiversity of the loess regions in Poland. Inventory, geoconservation issues, and geotourism potential. Quaternary International, 296, 68-81. DOI: https://doi.org/10.1016/j.quaint.2012.08.2057.

SZARVAS 2019: The Novohrad-Nógrád Geopark map. Official Szarvas András Website [cit. 2019-08-09]. Retrieved from: https://www.map.hu/Catalogue/Regional_maps Hungary/2_National_park_maps/novohrad-nograd-geopark-map.

UNESCO 2018: UNESCO Global Geoparks. Retrieved from: http://www.unesco.org/new/ en/natural-sciences/environment/earth-sciences/unesco-global-geoparks.

ZWOLIŃSKI, Z. 2004: Geodiversity. In Goudie, A. S. ed. Encyclopedia of Geomorphology. Vol. 1. London and New York (Routledge), pp. 417-418.

ŻABA, J., GAIDZIK, K. 2010: Geoturystyka - nowa interdyscyplinarna dziedzina nauk o Ziemi. Biuletyn Naukowy Wroctawskiej Wyższej Szkoty Informatyki Stosowanej. Turystyka i Rekreacja, 1, 6-13.

This study was produced as part of the statutory activity of AGH University of Science and Technology at Faculty of Geology, Geophysics and Environmental Protection in the Department of General Geology and Geotourism (agreement no 11.11.140.005).

\footnotetext{
Author's affiliation

Dr Elżbieta Gałka

Faculty of Geology, Geophysics and Environmental Protection, AGH University of Science and Technology

al. Mickiewicza 30, 30-059 Kraków

Poland

egalka@agh.edu.pl
} 